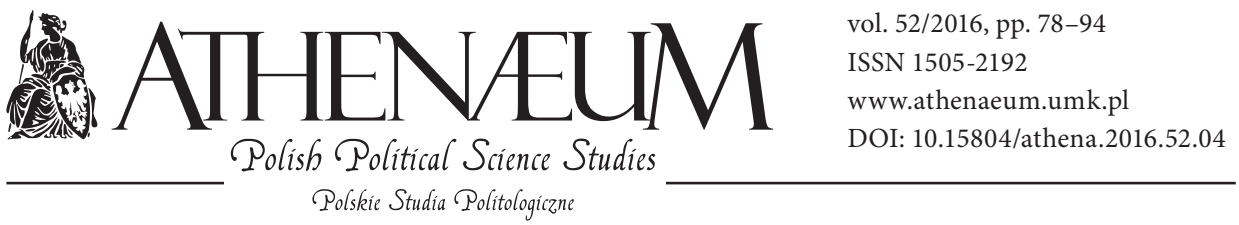

\title{
SOCIAL DIMENSION OF NEW TECHNOLOGIES IN BORDER CONTROL: AN INTERNATIONAL RELATIONS PERSPECTIVE
}

\author{
SPOŁECZNY WYMIAR ZASTOSOWANIA NOWOCZESNYCH \\ TECHNOLOGII KONTROLI OSÓB NA GRANICACH PAŃSTW \\ Z PERSPEKTYWY STOSUNKÓW MIĘDZYNARODOWYCH
}

Anna Moraczewska*

\begin{abstract}
The contemporary border crossing is said to have become progressively more automated and faster. Automated devices and surveillance systems in border control generally are to enhance security of the state. However, this perception of innovations in border control represents more of a developed countries' perspective than a universal rule. An acceleration of technological development maintains or deepens inequalities between countries, regions, societies or generations and the change (progress) does not occur worldwide and does not apply to all societies. This paper presents different systems of border control using new technologies and their consequences in social and human dimension. A transition of state's border from a physical line to territorially dispersed points, linked with international information and data sharing, is analysed. The impact of the automated border control of travellers
\end{abstract}

Kontrola na współczesnych przejściach granicznych jest coraz bardziej zautomatyzowana, a tym samym sprawniejsza. Polega na weryfikowaniu danych obecnych w systemach informacyjnych i pozwalających na zakwalifikowanie podróżującej osoby do grupy ludzi otrzymujących prawo wjazdu lub jego zakaz. Dla państw wysoko rozwiniętych są instrumentem zwiększania bezpieczeństwa swojego terytorium i obywateli oraz ich mobilności. Z punktu widzenia imigrantów napływających z obszarów ekonomicznie zapóźnionych czy politycznie niestabilnych wykorzystywanie elektronicznych baz danych do ich weryfikowania, poprzedzone koniecznością rejestracji przybyszów, a w przypadku jej braku koniecznością pozostawienia przez nich swoich danych biometrycznych, staje się dużą barierą lub utrudnieniem. Autorka przedstawia zmianę istoty funkcjonowania współczesnej granicy państwa

* Maria Curie-Skłodowska University, Department of International Relations. 
on interactions between developed and less or developing countries is on the main interests of the author in this paper.

Keywords: automated border control, social effects, digital divide, stratification w wyniku digitalizacji danych alfanumerycznych i biometrycznych osób przemieszczających się przez nią oraz skutki tego zjawiska dla społeczeństw w wymiarze międzynarodowym.

Słowa kluczowe: zautomatyzowana kontrola graniczna, skutki społeczne, cyfrowy podział, stratyfikacja

Biometrics are turning the human body into a passport or a password Emilio Mordini, Sonia Massari (2008)

The contemporary border crossing is said to have become progressively more automated and faster. Automated devices and surveillance systems in border control generally are to enhance security of the state. However, this perception of innovations in border control represents more of a developed countries' perspective than a universal rule. On the other hand, all travellers who wish to enter the Western world are subject to automated screening. Developed states link the act of crossing a border with databases recording each individual border crossing. Travelling through many states and their borders is still mostly a human-to-human interaction - or, more precisely, an encounter between an officer and a traveller. Despite the continuing presence of human relations during most border crossings, an inter-operable system and electronic up-inking 'travel with the traveller' and define his/her interaction with the border service or an automated gate. Many times, an individual's first contact with the border occurs via an electronic visa application form - a process with widely varying degrees of complexity depending on the country of origin and destination. Entities that are engaged in technology production and usage include states, constructors/innovators, industries/manufacturers, and, involuntarily, also travellers. Usually, technology creators hope to elicit interest in their innovations among governments and get a licence or patent; manufacturers strive for exclusivity and lucrative contracts; states strive to make border control more effective, and travellers hope to ease and accelerate their mobility across borders. The same technologies can play varying roles and be used for varying purposes by different entities. At the same time, disparate technologies can be applied with very similar aims in mind in different countries. Since the reality of the 
international environment is fast becoming increasingly complex and entangled, some states have started to use tighter border control as a means to manage this state of affairs. A multi-tool approach to border control compared to 'the Swiss Army Knife approach' by Chris Hurrey (2013, p. 285-288) sounds very rational and practical from its owner's side (the developed and innovative countries), but much less attractive from the point of view of immigrant groups from less developed countries.

An analysis of interactions between technology and society requires a broad knowledge based on new scientific concepts, theories and empirical investigations (Zacher, 2006, p. 123-148). It is relevant to observe and analyze these correlations in order to avoid or minimize their negative effects. The sociotechnology interactions can be investigated in transformations of civilization, creating new dimensions of quality of life and level of their advancement; in economic development of states and corporations investing capital in $\mathrm{R}+\mathrm{D}$ and facilitating man's every-day life; in trade-offs between manufacture of high-tech equipment, its innovation and then waste production, and ecological problems finally hitting human beings. From international relations perspective, an acceleration of technological development maintains or deepens inequalities between countries, regions, societies, or generations and the change (progress) does not occur worldwide and does not apply to all societies.

There are a number of methodological approaches to the phenomenon of technology and its social impacts. Due to the combination of two: humanistic and pure sciences, the investigated issue requires an interdisciplinary approach. Evaluation study, with technology assessment approach, serves to analyze (mainly negative) effects of technological advances, and is used in this article. The indirect, unintentional, or postponed social effects of technology can be examined using this approach. The sociological perspective concentrates on broad aspects of interactions between society and technology analysing different social subsystems in a macro and micro scales. Ulrich Beck (2002) based his idea of the 'society of risk' on uncertain consequences of human's modernisation through technological development. The effects, also recognized as consequences and influence, are results of interactions between a particular technology and its social context. They can be analysed within different disciplines: e.g. medicine (influence on human's health), psychology (consequences for social mentality and emotions), or economics (effects in the standard of living and development), and with various scope: referring to a small or big group of people, a group separated by a particular traits, local or international 
society, etc. In this article, the international relations perspective was chosen to indicate effects of new technologies, used during border crossing, to travellers migrating from developing and less developed countries to the developed one. Evaluation analysis applied in the paper consists of social impact assessment and international relations impact assessment in the context of the border crossing procedure and process.

In the context of territoriality of a boundary James Anderson, Liam O'Dowd and Thomas M. Wilson (2003, p. 7) affirmed that borders were meeting sites of different systems, most direct interactions and visible contradictions and hence they constituted a central component of the contradictory world system. Departing from the territorial context of boundary and referring to its electronic-virtual dimension, this statement is still valid. Therefore the main aim of this paper is to present different systems of border control using new technologies and their consequences in social and human dimension. Research problems concern: how the state border itself is transformed and shaped by new technologies and how technologies used in border crossing influence states' and social relation in international scope.

\section{A BORDER REVAMPED}

The term 'smart border', or 'intelligent border', is given many meanings, all of them derived from its technological dimension. To some extent, they are both self-managed and jointly managed by a system. This hints at their dynamic nature, consisting in permanently adapting to continually arising challenges posed by new threats and/or the rise of competing new technologies. The concept of the smart border also includes international agreements on rules of border crossing between countries which enable to optimise the usage of technological innovations and create linkages between countries.

Regarding new technologies, a contemporary border is said to be: a virtual fence, a spatially mobile border, a filter of risk. The first of these indicates that in a place of a permeable border, an additional obstacle is established that exists beyond the traveller's control but determines whether or not he or she enters the territory of a state. It also means that the border exists immaterially in cyberspace as a reservoir of digital information which makes it possible to assess security threats before they cross the border. Spatially mobile border suggests a dispersion of borders in the transnational and internal space through the creation of a trans- 
national network of information that 'journeys' together with traveller. (There is much more information in the system than in the passport or ID). Moreover, the utilisation of new technologies allows governments to export border control to the most desirable location - e.g. inland, to airports, or to space, thanks to the exchange of information between countries.

Risk analysis has become a crucial element of border security for most of the developed countries. It is based on data and information collection and calculation. The greater number of data, the more advanced data processing system. Its aim is to assess a situation picture at the border, some trends, by identification of possible threats and negative situations, determination of casual relationships between level of probability and severity of outcomes and evaluation of these results to apply instruments and strategies to reduce the risk or/and control it (Haimes, 2004, p. 54-55). Experts create possible scenarios for the future, (if they use a scenario method), by computer assistance in calculations and selection among millions of combinations. Risk analysis of the border situation picture increases prediction of threats and prevention against their diffusion inside the state. Detection of smuggling and illegal border crossing reduces hazards within the territory of the country. Some actions are taken directly at border crossings and another far from the border. The border becomes a filter of possible threats (risks) as a result of direct intervention at the border and information sharing between countries about their sources.

The de-territorialisation of the border in the context of new technologies refers to the experience of a first contact with border control that does not need to take place at an official state border, but within the online registration system, which decides the 'to be or not to be' of an individual entering a given country. De-territorialisation also implies the use of 'intelligent gates' at airports situated far from the territorial border, which can symbolise a departure from one country and entry into the territory of another when in fact the individual remains within the territory of the same state. On the other hand, de-territorialisation also takes place due to the transmission of digital information among states. Didier Bigo (2007, p. 9-14) uses an appellation - de-localised forms of border control which comprise remote control checks, sharing huge quantity of data, policing at a distance, etc., and transform 'focus of control, from territory to population. These are arguments for the assumption that the dynamic development of new technologies has expanded and revamped the border, taking it from a demarcated territorial line to an often dispersed system of control based on data collection, processing and transmission. 


\section{ELECTRONIC CONTROL SYSTEM FOR BORDER CROSSING}

Biometric and alphanumeric data are collected in an integrated database - a system collecting data on persons and objects (e.g. works of art) before they cross the border. These databases include, e.g., the Schengen Information System II (SIS II), the Visa Information System (VIS) in the European Union, and NEXUS and SENTRI in the USA. SIS II is a second-generation, large-scale information system, constructed after the EU enlargement (which expanded the Union by several post-Soviet countries, plus Malta and Cyprus) and replacing SIS I. It consists of one central system (situated in Strasbourg, France) and the national systems of each member state, as well as the relevant communication infrastructure between them transferring virtually encrypted data between the authorities responsible for these systems. The data include the following information on individuals: first name(s), surname(s), name(s) at birth, nationality(ies), aliases, date and place of birth, specific physical characteristics, sex, photographs, fingerprints, whether the person concerned is armed, violent or has escaped from a correctional facility, the reason for the alert, the authority issuing the alert, and a reference to the decision that gave rise to the alert (Reg. (EC) No 1987/2006). The amount of information in SIS II is so huge that the system has been in construction for several years, and is still expanding. The Visa Information System further builds on SIS with the exchange of visa data, thus facilitating checks at the external borders of the member states of the EU, fighting against fraud, preventing "visa shopping", and helping in the identification of persons who do not meet the requirements for entering the EU (Reg. (EC) No 767/2008).

A modernised European system of border management named the 'Smart Borders' package, proposed by the European Commission in 2013, is a step forward, but still in a tentative stage of existence. It consists of an Entry/Exit System (EES) (COM (2013) 95 final) and a Registered Traveller Programme (RTP) (COM (2013) 97 final). Its idea is to join both facilitations for thirdcountry travellers and security for the European Union by using state-of-the-art technology. This is a defensive security strategy against illegal border crossing and overstay based on an automated border control system with alphanumeric data and fingerprints, which are stored in a central repository. It is addressed to a select group of people, namely frequent travellers from third countries, including businessmen, students, researchers, and/or some workers. Before using RTP, hopefuls must apply and justify their intention of travelling, and the system decides if they can be defined as frequent or regular travellers. He/she receives 
a token with a technical specification made by the European Agency for the operational management of large-scale IT (eu-LISA).

The 'Smart Borders' package is reflected in the concept of Automated Border Control (ABC) - "an automated system which authenticates the electronic machine readable travel document or token, [...] relies on facial recognition as the basis for biometric verification" (Best Practice Operational Guidelines for Automated Border Control (ABC) Systems 2015). The system uses single or double automatic barriers - e-Gates and biographic and biometric readers as detection mechanisms. Its effectiveness is based on electronic systems of data and information collecting, storing and sharing between the EU Member States and non-members as SIS II, VIS, Eurodac, Eurosur. The European Union perceives the $\mathrm{ABC}$ as a system of facilitation, securitisation and cost-effectiveness for travellers. On the other side, since it is in the stage of implementation and evaluation, a risk assessment is recommended in order to assess how the automation has influenced on existing risks or risen new ones.

Similar systems that are also in widespread operation include SENTRI and NEXUS - registered-traveller programmes in which frequent travellers enrol by submitting information for criminal and terrorist background checks (Koslovski, 2011, p. 13). SENTRI is used along the U.S.-Mexico border at American ports of entry while NEXUS operates at the U.S.-Canadian border. When a person is enrolled in the NEXUS verification programme, he or she is given a radio frequency-enabled proximity card and the chip on this card is read when the person approaches the U.S.-Canadian border, automatically showing the inspector alphanumeric information as well as photographic identification. Another example of a database-reliant system featuring automated devices is the Global Entry programme, applied in the United States in the case of pre-approved, low-risk individuals, usually frequent international travellers. After the person in question completes the online application (which costs 100 USD), a detailed background interview and check take place in a Global Entry Enrolment Center indicated by the system. A photo and biometric information are collected during the interview. When the person is approved, he or she may enter the U.S. by using an automated kiosk situated at some airports. In the kiosk, the traveller presents his/her machine-readable passport, scans his/her fingerprints for data verification, and fills in a customs declaration (US Customs and Border Protection website). There is also the Electronic System for Travel Authorization (ESTA) for passengers travelling to the USA under the Visa Waiver Programme (VWP), which uses an online application and payment process. 
Almost every year a great number of new initiatives and pilot projects can be found among the current and future plans of the U.S. Department of Homeland Security. One of them is the "Behavior Assessor pilot programs built on the current Screening of Passengers by Observation Techniques (SPOT) by employing specialized behavioral analysis techniques to determine if a traveller should be referred for additional screening at the checkpoint" (Privacy Impact Assessment 2015). A comparable program called the Smart Entry Service operates in South Korea. It allows low-risk travellers to use e-Gates after collecting almost the same information as the Global Entry programme before the journey. Amsterdam Airport Schiphol operates a "Security Scan provided with a screening technology that safeguards personal privacy. A computer analyses images instead of a human operator by means of harmless millimetre wave technology" (Security Scan at Schiphol Airport 2015). The Security Scan does not use X-rays that pass through the body, as in most popular body scans. At Australia's international airports, one may go through self-processed and self-administered passport control instead of personal verification by border officers using SmartGate, which processes a passenger through data in the ePassport and face recognition technology. There is a two-step procedure: first, checking the eligibility of the traveller to self-process his/her passport; and second, to perform the identity check. A passenger may also watch a film on the Internet to learn how this works.

When the old 'physiognomic' methods of classification of immigrants entering the New World at the beginning of $20^{\text {th }}$ century is compared with contemporary electronic-based instruments, the perception of the human being as a social unit prevails in the latter over the close human-to-human contact of the former [Picture 1]. However, the one on the top gives an impression of objectification of a man.

A.

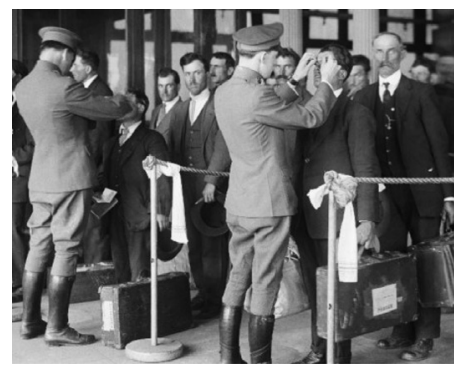

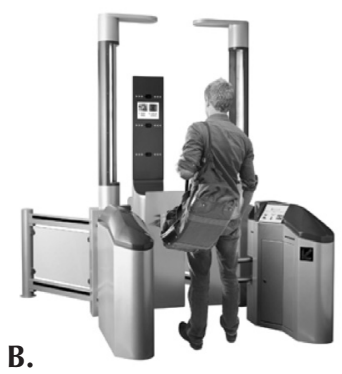

B.

Picture 1. The human factor at border checkpoints in the past (A) and today (B).

A. Inspection of immigrants at Ellis Island, USA, 1920. [www.daily.co.uk - April 12th, 2013]; B. SmartGate in Australian international airports, 2015 [www.border.gov.au Arrivals SmartGate] 


\section{A DIGITAL DIVIDE}

The divide between developed and less developed countries (LDC) is one of the most common criteria used when analysing the various factors underlying contemporary international relations. Neo-technology theories of trade are based on the existing differences between states in the level of innovative services or products offered, pointing to mutual benefits for countries that produce and export them as well as countries that do not have sufficient amounts of capital and know-how and import them. To a large extent, this is true. But steadily accelerating technological advances (also resulting from increasing competition between the enterprises producing them) deepen an already large development gap between developed and less developed countries.

The Measuring Information Society Report, published by the International Telecommunication Union every year, presents information and communication technology developments in regions and countries across the world. The 2014 edition states that " 4.3 billion people are not online and 90 per cent of them live in developing world" (Measuring Information Society Report 2014, p. 21). Instead of a continuing surge in the number of Internet users in all countries under examination (166), the gap between developed and developing states persistently refuses to close. If the average fixed broadband penetration is 9.8 percent in the world, Europe's one is almost three times higher (27.7), while in the Arab States penetration is more than three times lower (3.1\%). For Africa, this indicator is 0.4 percent, which is 24 times smaller than the world average and 70 times smaller than Europe's. The pattern repeats itself when the percentage of households with Internet access is considered. 78 percent of European households have access to the Internet while 11 percent of households across Africa enjoy the same. Another survey conducted by the United Nations based on the E-Government Development Index (EGDI) indicates an increase of e-government and e-participation services in most regions, but also high disparities between a group of high-achieving countries in Europe and the Americas, and a group comprising Africa and Oceania, which remain below the world average (United Nations E-Government Development Index 2014) These last two indicators represent the possibilities and effectiveness of, e.g., obtaining the documents required to apply for a visa. The skills gained in the process of regular use of computer and the Internet determine human abilities and effectiveness in coping with contemporary requirements for free and legal crossing of the borders of the developed world. 
Among a group of countries ranked by Information and Communication Technology Development Index (IDI), the rift between the top ten and the bottom ten is, on average, seven points (with 10 as the highest and 0 as the lowest). Eight of the top ten countries are in Europe, with Denmark as a front-runner. This country earned 8.86 points, while Luxembourg, with 8.26 , placed tenth. On the opposite extreme, the Central African Republic scored 0.96, placing last. The states that preceded it in the list, in ascending order, were: Niger, Chad, Eritrea, Ethiopia, Guinea, Madagascar, Mozambique, Malawi, Congo, and Burkina Faso, with 1.56 as the highest score among this bottom ten - all from the African continent.

The progress of new technologies generates profits, nourishes economic booms, and actuates socio-economic development. On the other hand, its speed is inversely proportional to the process of reduction of disparities between highly-developed and less developed countries. As a consequence, technologydriven economies double their benefits by enhancing security and increasing profits, and the electronic control systems in border crossings perpetuate the growing digital divide between developed and less developed countries.

\section{THE SOCIAL IMPACT ASSESSMENT OF ELECTRONIC BORDER IMPLEMENTATION}

The social effects of employing high-tech devices and electronic control systems are usually presented favourably as facilitator and rationalisation of inspections at ports of entry. A self-check in a smart gate is easy when preceded by a preregistration in a state's visa application or leaving one's biometric and alphanumeric data in the system beforehand. Moreover, electronic systems of border control carry benefits in the form of augmented safety for travellers and an increased flow of people. In a broader sense, another advantage is the collection and analysis of personal data before the person enters the port, because border inspectors can focus on more high-risk travellers and carriers, e.g. smugglers, and strengthen border security. As a consequence, automated border control is perceived as a facilitator and mobility accelerator for societies in technologydriven countries.

Many people in poor or less developed countries do not have access to the Internet or have not even used computers in all their lives. On the other hand, many of them would like to change their living conditions and cross a border 
into the developed world. In 2013 UNICEF (2013) calculated that 230 million of births worldwide were unregistered, hence those children lacked any form of identification. Most newborns come from South Asia (103 million), Sub-Saharan Africa ( 85 million). This is why some of the more determined prefer to risk illegal human trafficking rather than a long administrative journey with bureaucrats and automated machines situated sometimes hundreds of kilometres away from their villages. Another barrier could be the use of overly complex language in an application, usually based on cultural patterns of communication. As an example, the three alternatives in the choice of an applicant's gender (Female, Male, Other) in some applications might be controversial for some nations or cultures, while the lack of such options may be perceived as discriminatory in others. In addition, oftentimes there is a limited selection of languages in which one can fill out the application, as in the U.S. visa application form (though there is an electronic translator assistant). Above all, however, what is required are computer skills, which may not be so common in many LDC, and Internet connection speeds will also determine the time their citizens spend on this process. As a result, automated border control is perceived as an intricate system and an intangible barrier restricting the free flow of people for societies living in the least connected countries.

Certain determinants that create human perceptions of new technologies when crossing the border can be distinguished. First among them is the level of economic, scientific, and innovation development. The second is the level of education and technical culture (intellectual and techno-knowledge development), while the last is the prevailing political and institutional system (Zacher, 2012, p. 391-397). On this basis, three types of countries according to the social dimension of new technology can be distinguished:

- states with socially effective techniques;

- states with socially ineffective techniques;

- states with socially ambiguous effectiveness of techniques.

The first group includes the most developed, innovative states, where technologies fulfil most of society's expectations while the state itself represents innovators, producers, and consumers at the same time. Within this group are the U.S., Canada, most members of the EU, and some associated countries, Australia, New Zealand, South Africa, Japan, Israel, Singapore, and South Korea.

The second group consists of less developed countries whose situation is opposite to the first group and where new technologies greatly reduce the effectiveness of the objectives on a societal and governance level. These are countries with 
a low GDP, less connected with the world, and the lowest scored in the Measuring Information Society Report (Measuring Information Society Report 2014).

The third group is more heterogeneous and consists of developing countries that are effective in one dimension. Among them are states which are not innovators or constructors of new technologies, but use them effectively on both individual and national level. These are the new member states of the EU, Russia, Iran, Brazil, and some others. Meanwhile China can be described much less as an innovator than as a producer and consumer of new technologies, focused on effectiveness of the objectives mainly on state level rather than the small-scale social level.

This classification with reference to the issue of automated and electronic systems in border crossing is adequate and expressive. A state with socially effective techniques spends a lot of money and invests in high-tech electronic devices that aid with border control as well as interoperable systems of data transmission to enhance its security, boost its economy, and ensure progress and influence on other states. In effect, this group of states, to some extent, becomes a regulator of international migrations. Analogously, a society draws advantages through offering fast and easy border crossing, facilitating measures to ensure common access to electronic documents without leaving home, and the possibility to travel to one's desired destination.

Another group of states is isolated from the benefits of technological advance and financial profits. Their societies cannot fully incorporate electronic devices of communication or maintain limited use of them in the face of myriad formal and technical obstacles in applying for visa or crossing the border of a state from the first group. This society becomes subject to verification and authentication, mainly determined by the state of origin.

The last group represents states which are connected to electronic data systems involving travellers on various levels. These states apply elements of automated border control. Most of them adapt their border control systems to their inventor and constructor, enabling their societies to benefit from freedom of movement between countries and thereby generate indirect benefits for themselves. On the other hand, some political regimes, with many conflicts on the borders, prefer to spend money on new weapon technologies to shoot 'illegal aliens' crossing the border than on new registration and control technologies that are to facilitate human mobility.

Nancy Wonders (2006, p. 64) notes that even though globalisation had the great potential to reduce inequality, 'electronic surveillance' at border crossings 
has boosted global stratification. (She indicates the U.S.-Mexico border as the most evident instance of inequality in the human, economic, and power dimensions). The issue of relations between technology and society becomes more important due to the continuous rapid technological progress, the development of the information society, but also the increased risk posed by coupling between these issues. Investments of the developed countries in technology and knowhow bring them benefits on the world market, increase security and progress for their societies. A kind of techno-network is emerging that creates cohesive and conflicting interactions. There are the entities that produce and use technologies, assist them financially and politically, achieve advantages on the market and use them to monitor and eliminate hazardous factors. On the other hand, there are those whose freedom is limited by technologies, who are afraid of them or are excluded in one way or another.

\section{THE INTERNATIONAL RELATIONS IMPACT ASSESSMENT OF ELECTRONIC BORDER CONTROL}

Comparing a group of states with high rankings in the Information Society Report (ISR) and IDI to the group of least connected states with the lowest ISR rank, using net migration criteria, the first group has a long-lasting negative migration rate while most countries from the last group are characterised by a positive migration rate. This results in a feedback loop between net migration and the technological development of states, where the usual immigration countries try to control this tendency by increasing quality and technological advancement among their instruments of border control. From the international relations perspective, this kind of behaviour leads to the establishing of some rules used between entities that in effect create a system of specific interactions. A systemic approach allows us to holistically present these relations between the two groups and their social effects [Picture 2].

The actions of states that own new technologies for border control and capital to develop and advance them catalyse two asymmetric social effects within their external and internal environment. Inside their system, whose degree of complexity may vary, they invent, produce, and use new technologies to facilitate border crossing and enhance mobility for their citizens. As a result, they extend the possibilities of travel and bring conditions of border crossing closer to the needs of this society. Moreover, bilateral or multilateral agreements in intelligence or/ 


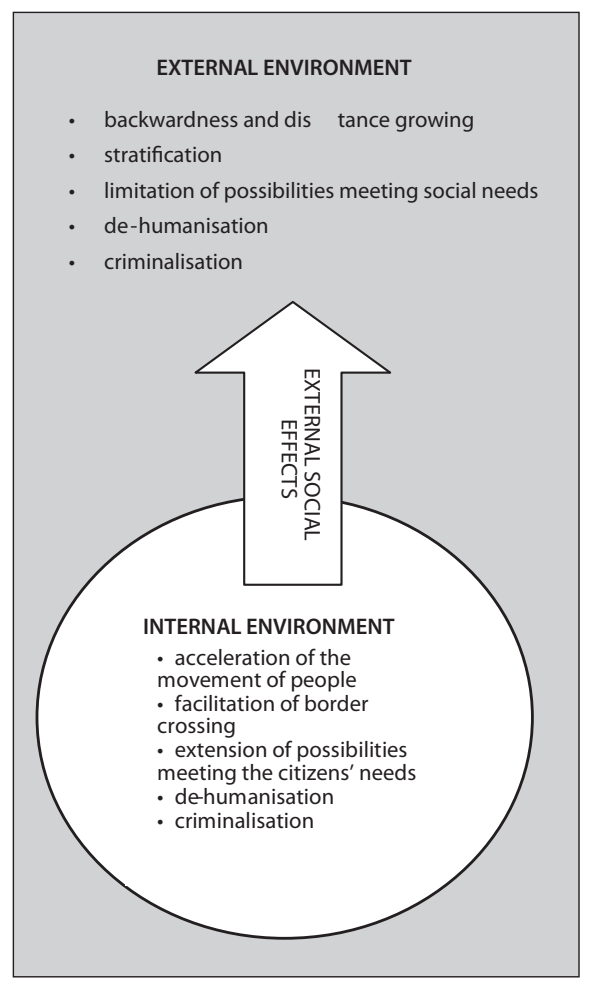

Picture 2. Asymmetry in social effects of new technologies in border control between developed and less developed economies.

Source: Author's elaboration.

and data sharing among these states build a framework that extends a range of possibilities for the society of technologically advanced countries, and a range of limitations for the societies of LDC. The effects of this for a society are the de-humanisation and 'criminalisation' of travellers. The first consists of limiting human-to-human contact, which, depending on individual know-how and cultural patterns, can be assessed positively or negatively by people. 'Criminalisation' refers to the collection and storing of biometric data for all travellers - raising suspicions and feelings of hostility from all of them. However, most of them accept this procedure in exchange for a sense of greater security.

The same automated border control systems and electronic data processing used by developed countries cause quite different social effects in the external environment beyond these states. These include economic backwardness and growing divides in relation to other countries, stratification, and limited possibilities of meeting social needs. In their first interaction with electronic devices 
at border crossings, the societies of many LDC often feel a mental barrier and skills barrier. A kind of formal barrier can appear when a citizen does not have all the required documents to apply for a visa. The effects that occur for both societies - in developed and less developed countries - are not the same for individual groups. While procedures resulting in 'criminalisation' at border checkpoints are seen through the lens of individual security by societies from developed countries, travellers from poor countries feel more suspicious than secure. In addition, some immigrants' personal situation can be very complicated - culturally or politically determined, and the electronic system for recording and smart-gates may not include such options in the system.

While Didier Bigo (2007, p. 9-14) has not made any distinction between elements of an electronic system of border control in the global context, he used a pertinent term - 'trace' - which had a crucial role in sorting out and giving a specific profile for groups and individuals in border crossing. This process consists in 'tracing' someone's movement, analysing it and giving a precise trajectory. These who execute it are mostly states with socially effective techniques and several with ambiguous effectiveness of techniques, and those who are 'traced' belong usually to states with socially ineffective techniques. On the other hand, every citizen from developed countries should be 'traced' if he/she wants to be given a trajectory complement with his/her own.

\section{CONCLUSIONS}

The securitisation of the border through its technologisation is a comprehensive process based on high-tech equipment, state policy, and market demand. The social factor is one of several others considered by states who can afford expenditures for new technologies in their policy of securitisation. It is much less important for countries that are 'technologically challenged'.

Societies from technology-driven economies are able to benefit the most from the opportunities offered by the innovation process. Automated border control enables them to go through fast and easy border control and gives them the notion of being safer. On the other hand, the least connected, low-income countries invest neither in comprehensive technology for border checks nor in electronic databases and documents to facilitate and enhance international mobility for their citizens as well as for foreigners visiting their countries. I conclude that there is a continuing expansion in the range of choices for people who 
are able to travel freely - and a continuing narrowing of the field of choices for those who have limited or no conditions to travel abroad.

The efficiency of the contemporary border, in most developed countries, relies on filtering and analysing of big data in order to prevent those countries from highly or less probable threats which may appear at the physical border line. A great part of the decision on border crossing is taken away from the physical border line, by the group of experts analysing big data, using computer systems and without being in any contact with the real border-crosser. The pre-border control, based on intelligence gathering and risk assessment, has been defined as a border management in national policies of developed states. The European Union's exemplification of this policy Didier Bigo (2014) names "the management of flows of people through figures at EU-LISA" (p. 217). On the other side, border guards or 'border experts in data analysis' can have an impression that the decision is taken by a huge electronic data processing system and they just implement it, or even are replaced by machines in that.

\section{REFERENCES:}

Anderson, J., O’Dowd, L., Wilson, T.M. (2003). New Borders for a Changing Europe: Cross-Border Cooperation and Governance, Routledge Series in Federal Studies. London: Tylor \& Francis.

Beck, U. (2002). Społeczeństwo ryzyka - w drodze do innej nowoczesności. Warszawa: Scholar.

Best Practice Operational Guidelines for Automated Border Control (ABC) Systems, (2015) Research and Development Unit - Frontex. Retrived from: http://frontex.europa.eu/ assets/Publications/Research/Best_Practice_Technical_Guidelines_ABC.pdf, p. 10.

Bigo, D. (2007). Mobility Controls and New Technologies. In: J. Lodge (ed.), Are You who you say you are? The EU and Biometric Borders (p. 9-14). Nijmegen: Wolf Legal Publishers.

Bigo, D. (2014). The (in)securitization practices of the three universes of EU border control:

Military/Navy - border guards/police - database analysts. Security Dialogue, 45 (3), 209-225.

COM (2013). 97 final, Brussels, 28.2.2013, Proposal for a Regulation of the European Parliament and of the Council establishing a Registered Traveller Programme.

COM (2013). 95 final, Brussels, 28.2.2013, Proposal for a Regulation of the European Parliament and of the Council establishing an Entry/Exit System (EES) to register entry and exit data of third country nationals crossing the external borders of the Member States of the European Union.

Haimes, Y.Y. (2004). Risk Modeling, Assessment and Management. New Jersey: Wiley Publication. 
Hurrey, Ch. (2013). The 'Swiss Army Knife' Approach to Border Control. Multitasking in a Multi-threat World. Intelligence and Security Informatics Conference. DOI 10.1109/ EISIC.2013.73.

Koslovski, R. (2011). The Evolution of Border Controls as a Mechanism to Prevent Illegal Immigration. Washington DC: Migration Policy Institute Press.

Measuring Information Society Report (2014), International Telecommunication Union, Switzerland 2014. Retrieved from: http://www.itu.int/en/ITU-D/Statistics/Documents/publications/mis2014/MIS2014_without_Annex_4.pdf.

Modrini, E., Massari, S. (2008). Body, Biometrics and Identity. Bioethics, 22 (9), 488-498. DOI: $10.1111 / \mathrm{j} .1467-8519.2008 .00700 . x$.

Privacy Impact Assessment for the Screening of Passengers by Observation Techniques (SPOT) Program, U.S. Department of Homeland Security. Retrieved from: https:// www.dhs.gov/xlibrary/assets/privacy/privacy_pia_tsa_spot.pdf.

Reg. (EC) No 1987/2006. Regulation of the European Parliament and of the Council of 20 December 2006 on the establishment, operation and use of the second generation Schengen Information System (SIS II).

Reg. (EC) No 767/2008. Regulation of the European Parliament and of the Council of 9 July 2008 concerning the Visa Information System (VIS) and the exchange of data between Member States on short-stay visas (VIS Regulation).

Security Scan at Schiphol Airport. Retrieved from: file://C:/Users/AM/Downloads/85527_SPL_Security_Scan_HR.pdf.

U.S. Customs and Border Protection. Retrieved from: http://www.cbp.gov/global-entry/ about.

UNICEF (2013). United Nations Children's Fund, Every Child's Birth Right: Inequities and Trends in Birth Registration. New York: UNICEF.

United Nations E-Government Development Index. Retrieved from: http://unpan3. un.org/egovkb/global_reports/index.htm.

Wonders, N. (2006). Global Flows, Semi-permeable Borders and New Channels of Inequality. In: S. Pickering, L. Weber (eds.), Borders, Mobility and Technologies of Control (p. 63-86). Dordrecht: Springer. DOI: 10.1007/1-4020-4899-8_4.

Zacher, L.W. (2006). Co-existence of sciences (from mono to post-disciplinarity). Theory of Science, XV/XXV/III (3), Academy of Science of Czech Republic, 123-148.

Zacher, L.W. (2012). Ocena techniki i jej skutków jako wyzwania dla polityki. In: L.W. Zacher (ed.), Nauka, technika, społeczeństwo. Podejścia i koncepcje metodologiczne, wyzwania innowacyjne i ewaluacyjne (p. 391-400). Warszawa: Poltex. 